\title{
¿Una Transición mágica? Entre la alegoría política y el discurso marginal ${ }^{1}$
}

\author{
A magical transition? Between political allegory and marginal discourse
}

\author{
Luis Bagué Quílez \\ lbague@um.es \\ Universidad de Murcia, España
}

Recepción: 12 Agosto 2019

Aprobación: 10 Mayo 2020

Publicación: 15 Mayo 2020

Cita sugerida: Bagué Quílez, L. (2020). ¿Una Transición mágica? Entre la alegoría política y el discurso marginal. Olivar, 20(31), e072. https://doi.org/10.24215/18524478e072
Resumen: En este artículo se abordan una serie de obras adscritas a lo que he denominado "una Transición mágica", pues todas ellas privilegian una aproximación simbólica a la realidad, en contraste con la poesía figurativa que predominará en la década de los ochenta. En concreto, se analizan la alegoría (intra)histórica contenida en Primer y último oficio (1979), de Carlos Sahagún; la épica coral desarrollada en Un país como este no es el mío (1978), de José Antonio Gabriel y Galán; la taumaturgia lírica mostrada en Taller del hechicero (1979), de Aníbal Núñez, y Teoría y práctica del círculo (1979), de Juan Luis Ramos; y, finalmente, los paraísos artificiales desplegados en Primavera soluble ([1978] 1992), de Aníbal Núñez, y De una niña de provincias que se vino a vivir en un Chagall (1981), de Blanca Andreu. Entre la parábola política y el discurso marginal, los títulos anteriores reflejan la personalidad creativa de unos autores que se alejan de sus respectivos paradigmas generacionales y que ofrecen una perspectiva disidente sobre un país en transición desde el posfranquismo hacia la democracia.

Palabras clave: Transición democrática, Pesía española de los ochenta, Carlos Sahagún, José Antonio Gabriel y Galán, Aníbal Núñez, Juan Luis Ramos, Blanca Andreu.

Abstract: This paper deals with a number of works ascribed to what I have called "a magical transition", since all of them privilege a symbolic approach to reality, in contrast to the figurative poetry that prevailed in the eighties. Specifically, I focus on the (intra)historical allegory contained in Primer $y$ último oficio (1979), by Carlos Sahagún; the choral epic developed in Un país como este no es el mio (1978), by José Antonio Gabriel y Galán; the lyrical thaumaturgy shown in Taller del hechicero (1979), by Aníbal Núñez, and Teoría y práctica del círculo (1979), by Juan Luis Ramos; and, finally, the artificial paradises displayed in Primavera soluble ([1978] 1992), by Aníbal Núñez, and De una niña de provincias que se vino a vivir en un Chagall (1981), by Blanca Andreu. Halfway between political parable and marginal discourse, these titles reflect the creative personality of certain authors who do not conform to their respective generational paradigms and then offer a dissenting perspective about a country in transition from post-Francoism to democracy. 
Keywords: Democratic transition, Spanish poetry of the eighties, Carlos Sahagún, José Antonio Gabriel y Galán, Aníbal Núñez, Juan Luis Ramos, Blanca Andreu.

\section{PoÉticas EN TRANSICIÓN}

En su ensayo Moratín y la Ilustración mágica (1972), Luis Felipe Vivanco planteaba una peculiar reinterpretación del pensamiento ilustrado de Leandro Fernández de Moratín. Frente al dramaturgo encerrado en la cárcel de las tres unidades y consagrado a la difusión pública del docere horaciano, el artífice del libro advertía la sombra de otro Moratín menos conocido, pero acaso más interesante: el que redactó unas crónicas de viaje por Italia e Inglaterra que oscilan entre el dietario y la novela, o el que realizó unas anotaciones jocosas y palimpsestuosas a propósito del auto de fe celebrado en Logroño, en 1610, y cuya relación debemos a la pluma de Juan de Mongastón. Las irreverentes glosas de Moratín al juicio de las brujas de Zugarramurdi nos permiten asomarnos a la personalidad de un autor "transicional" que, sin embargo, no llegó a atravesar el umbral de la razón para sumergirse en los territorios oníricos e imaginativos que colonizaron los aquelarres pictóricos de Goya. Como afirma Vivanco (1972, p. 15), "Moratín [...] es escritor a caballo entre el XVIII y el XIX, sin entrar en el romanticismo, ni siquiera en ese momento final de la Ilustración tan extraordinario, al que podríamos calificar de mágico".

El anterior excurso podría aplicarse al paisaje cultural de la Transición democrática española. En dicho periodo nos encontramos también con un impasse del que dejan constancia algunas propuestas que pretenden transcribir el clima histórico a través de un código simbólico más cercano a la distorsión visual de Goya que a la lógica cartesiana de Moratín, desde la película-emblema de la época-Arrebato (1979), de Iván Zulueta - hasta los artefactos narrativos de Miguel Espinosa, Germán Sánchez Espeso o Julián Ríos, pasando por las performances teatrales de Fernando Arrabal, Francisco Nieva o Miguel Romero Esteo. Con el tiempo, esa otra Transición acabaría engullida por una normalización democrática que parecía exigir un "realismo posmoderno" (Oleza, 1996) para traducir la atmósfera política y la sensibilidad ideológica de los años ochenta.

Si nos ceñimos a la poesía, entre 1979 y 1980 se publican dos antologías representativas de los caminos por los que iba a discurrir la lírica en los años siguientes. La primera, Joven poesía española (1979), coeditada por Concepción G. Moral y Rosa María Pereda, era una antología de cierre que daba carta de naturaleza a la archiestética novísima y exhibía los primeros síntomas de mineralización temática y agotamiento estilístico: el abigarramiento culturalista, la escenografía neovanguardista y la indagación metapoética constituían los tres pies sobre los que se levantaba una nómina que ampliaba la longitud de onda del radar castelletiano para acoger a otros nombres fácilmente asimilables al paradigma generacional. Frente a esta selección, Las voces y los ecos (1980), recopilada por José Luis García Martín, abanderaba un movimiento “contrarreformista”. Esta antología promovía un relevo estético, aunque no generacional - los integrantes eran de la misma quinta que los "novísimos", si bien algo menos precoces en su irrupción editorial -, al tiempo que avanzaba las líneas de la "poesía figurativa" (García Martín, 1992): el clasicismo desprovisto de oropel culterano, la reprivatización subjetiva, la meditación elegiaca o la reescritura de los lugares comunes de la tradición literaria.

Entre 1979 y 1981 se difunden asimismo una serie de libros "disidentes" de autores de distintas generaciones: Un país como este no es el mio (1978), de José Antonio Gabriel y Galán; Primavera soluble (compuesto en 1978, aunque publicado en 1992), de Aníbal Núñez; Primer y último oficio (1979), de Carlos Sahagún; Taller del hechicero (1979), de Aníbal Núñez; Tiempo y práctica del círculo (1979), de Juan Luis Ramos; y De una niña de provincias que se vino a vivir en un Chagall (1981), de Blanca Andreu. Con las excepciones de Carlos Sahagún - perteneciente al furgón de cola del cincuenta - y Blanca Andreu - perteneciente a la avanzadilla de los ochenta -, los tres poetas restantes se encuadran en el marco 
sesentayochista, aunque ninguno de ellos figuró en ninguna de las dos antologías antes mencionadas. No es de extrañar esa ausencia, habida cuenta de que estamos ante una estética que rehúye tanto el cliché novísimo como el giro hacia la figuración. Los títulos anteriores coinciden en su voluntad de dar cuenta de las mutaciones históricas mediante una densidad simbólica que se opone al sociolecto realista que terminaría triunfando pocos años después. Ya sea desde una perspectiva política (en los ejemplos de Sahagún y de Gabriel y Galán) o desde una perspectiva marginal (en los casos de Núñez, Ramos y Andreu), el discurso que defienden sus creadores traspasa el cristal mimético para mostrarnos el apabullante trasmundo de una Transición mágica.

\title{
Una Alegoría (intra)histórica: Primer y Último oficio
}

\section{Redactado entre 1973 y 1977, Primer y último oficio fue también la última entrega poética de Carlos}

Sahagúnantes de dar la callada por respuesta y asumir su irrevocable vocación de bartleby, según el evangelio de Vila-Matas (2000). El libro, no obstante, gozó de cierta notoriedad por obtener el premio "Provincia" de León y, más tarde, el Premio Nacional de Poesía. En este trabajo me centraré en la tercera sección del volumen, que se abre con un pórtico titulado elocuentemente "País natal". En efecto, la citada sección despliega una secuencia cronológica de la intrahistoria terminal del franquismo, desde la vigilia que precede a la muerte anunciada del dictador hasta el desengaño ulterior. Los tres poemas centrales de este apartado "Septiembre 1975", "Libertad inmediata" y "Para este otoño súbito" aluden a otros tantos acontecimientos relevantes en el horizonte político del periodo: las últimas ejecuciones ordenadas por el régimen (el fusilamiento de cinco activistas de ETA y FRAP), la noticia de la muerte del dictador y los fastos de su entierro en el Valle de los Caídos (Mainer, 1996, p. 23).

Una de las singularidades de este apartado es la poetización del compromiso que asume Sahagún (Bagué Quílez, [2017] 2018, pp. 142-143). En primer lugar, escuchamos la voz de un "nosotros" generacional que se corresponde con la de los "niños de la guerra", quienes han heredado la derrota por la vía genealógica. En segundo lugar, la noche se erige en la principal “isotopía figurativa” (Romarís Pais, 2002, p. 361), en la medida en que la oscuridad implica la sombría perpetuación del sistema y la luz encarna el anhelo de cambio. En tercer lugar, llama poderosamente la atención la actitud desencantada que adopta el "narrador" de estas secuencias, en las que aparecen temas como la cobardía moral de los vencidos o la capitulación ideológica de los supervivientes.

"Septiembre 1975" y "Para un otoño súbito" resultan significativos de este enfoque. En el primero, la acotación cronológica orienta la lectura:

\author{
SEPTIEMBRE 1975 \\ Como un filtro bebido en copa sucia, \\ arma implacable, la vejez degrada \\ la noche del tirano. En ella, hundiéndose \\ entre las incidencias del otoño, \\ cinco vidas segadas descendieron \\ hacia la sombra, no hacia la derrota, \\ símbolos de un presente envilecido \\ que lentamente y sin piedad acaba... \\ Y, más allá de la crueldad del tiempo, \\ los que fuimos testigos somos cómplices. \\ Por ello, en el silencio roto, mientras \\ la lluvia cae sin tregua y sin destino, \\ aunque sepamos que la historia un día \\ rescatará esta página sangrienta, \\ la certidumbre airada de sus muertes \\ hoy nos atañe a todos: desarmados,
}


errantes ya y sin gloria, ¿’somos dignos de entrar en las regiones transparentes que ellos, cayendo hacia lo oscuro, alzaron con su pasión de luz, con su martirio?

(Sahagún, 2015, p. 208)

El poema se centra en el sacrificio de unos mártires laicos que han entregado sus vidas a cambio de la libertad (a ello remite el sintagma "cinco vidas segadas") ${ }^{2}$. Junto con el homenaje a las víctimas de la dictadura, el texto incluye una diatriba contra la culpabilidad colectiva de quienes han decidido mantenerse en silencio: a ello apuntan expresiones como "los que fuimos testigos somos cómplices", "hoy nos atañe a todos" o "isomos dignos / de entrar en las regiones transparentes [...] ?”. Hallamos también, al igual que en las demás composiciones de esta sección, abundantes marcas temporales ligadas a la declinación — "vejez” , "otoño", "presente envilecido", "crueldad del tiempo" - y un claroscuro anímico que se bifurca en dos direcciones: la pervivencia residual del franquismo, vinculada a la oscuridad y la caí da - "la noche del tirano", "descendieron / hacia la sombra", "cayendo hacia lo oscuro" - , y la resistencia política, asociada a la luz y la elevación - "regiones transparentes", "alzaron”, "pasión de luz” — . En este sentido, se rastrean huellas intertextuales que dialogan con la tradición mística y, más específicamente, con la mística telúrica de Claudio Rodríguez: de hecho, las retracciones y retractaciones habituales en el discurso de Sahagún ("descendieron / hacia la sombra, no hacia la derrota") recuerdan a las sinuosidades verbales del zamorano ("estamos en derrota, nunca en doma", se afirma en el poema "Lo que no es sueño", de Alianza y condena).

La proyección simbólica de "Septiembre 1975" tiene continuidad en "Para este otoño súbito", que puede leerse como el reverso desencantado de "Epitafio sin amor" (Estar contigo, 1973). Si este anticipaba con ironía profética la muerte del dictador y la carcoma del régimen franquista, hasta culminar con una nota esperanzada ("Fue posible por fin la primavera"), "Para este otoño súbito" se limita a certificar la defunción del tirano mediante una iconografía funeraria de tintes expresionistas:

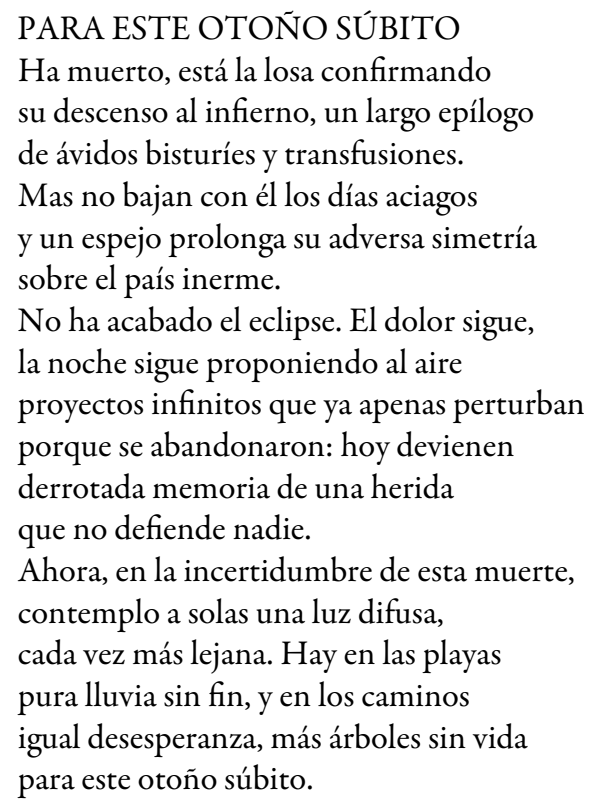

(Sahagún, 2015, p. 210)

Como sucedía en "Septiembre 1975", lo más interesante reside aquí en un claroscuro moral que no identifica la Transición con nuevo un amanecer, sino con un largo eclipse: así lo avalan fragmentos como "la noche sigue" o "luz difusa". En tanto que la lluvia cumple un papel testimonial, lejos de toda purificación catártica, el paisaje adquiere una tonalidad grisácea, deshumanizada y "póstuma” ("país inerme” y "árboles sin vida”). De esta manera, el particular código elocutivo de Sahagún refleja una mirada disconforme 
sobre el espacio transicional. La primavera anticipada que sugería el desenlace de "Epitafio sin amor" se ha reemplazado, un lustro después, por un otoño eterno con el que el autor nos previene del riesgo de una “integración acrítica en el nuevo sistema” (en $A B C, 1980$, p. 30).

En suma, la alegoría intrahistórica de Primer y último oficio supone una invitación a mantenernos en guardia ante una Transición fundada en los pactos de silencio y la bancarrota de las ilusiones utópicas, y en la que las heridas abiertas tras la Guerra Civil seguirían sin cauterizar.

\section{UNA ÉPICA CORAL: UN PAÍS COMO ESTE NO ES EL MÍO}

Escrito en 1976 y publicado en 1978, Un pais como este no es el mio, de José Antonio Gabriel y Galán, se relacionó tempranamente con una de las tendencias que empezaban a distinguirse con nitidez al filo de los ochenta: la "nueva épica" (López, 1979; Molina Campos, 1979, pp. 87-89) o la épica coral ${ }^{3}$. Diversos rasgos del libro justificaban dicha filiación: la indagación en la identidad colectiva, la superposición de modalidades discursivas (diálogo, monólogo, narración), el versolibrismo de aliento versicular o las imágenes de cuño irracional, en las que se filtraba una atmósfera onírica y perturbadora. A esta adscripción contribuyó igualmente la influencia del Anábasis (1924) de Saint-John Perse, que el propio Gabriel y Galán traduciría en 1983: por una parte, en ambas obras destaca la presencia de un poeta-demiurgo que actúa como portavoz de la colectividad; por otra, las dos comparten una estrategia retórica elíptica y fragmentaria donde el encadenamiento de secuencias aparentemente autónomas provoca una impresión de totalidad. A pesar de estas conexiones, Un país como este... se concibe como una reflexión histórica original sobre la desintegración del régimen franquista (Bagué Quílez, 2010, p. 54) que se articula en torno a dos ejes temáticos: una revisión imaginativa de la posguerra y una actualización del tema de España, mediante un paisaje fantasmagórico que choca con la precisa demarcación espaciotemporal.

El libro se organiza como una escenificación trágica cuyos personajes principales son el "depredador" - un antihéroe animalizado que funciona como trasunto del general Franco-, el pueblo anónimo - el coro de la tragedia, que representa el linaje de los perdedores -, los cómplices del poder - las autoridades militares o eclesiásticas - y los testigos externos - los espectadores del drama, a quienes se apela ocas ionalmente - . Esta puesta en escena sirve de excusa para introducir motivos como la dignidad moral de la derrota o la recuperación de la memoria, dos asuntos que se incorporan a través de un juego dialéctico entre el habla y la mudez, según se observa en los siguientes pasajes:

Los rostros desvaídos de las ventanas desconfiaban.

Nos enseñó una nueva forma de marchar,

las manos enguantadas,

y la inmensa tormenta de los ojos

comenzó a retumbar en nuestro ánimo.

Mostró el depredador sus lejanías,

nunca se vio su risa,

sediento y contenido,

pocos pudieron aproximarle.

Él saludaba en nombre del año de la victoria.

(Gabriel y Galán, 2010, p. 146)

En un país de subterráneos y desaparecidos

el silencio es el mismo que en la ciudad altiva,

pantano de lechuzas

y de niños sin dedos.

(Gabriel y Galán, 2010, 152)

Tanto fue aquel silencio solo roto por negros caracteres en los muros. 


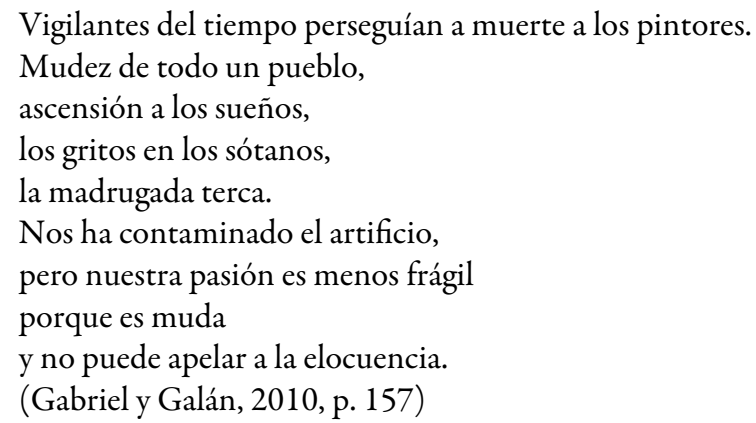

La confusión de voces y ecos subraya el contraste entre el lenguaje del poder (el grito) y el del pueblo (el silencio). Así, la violencia dictatorial desemboca en la algarabía y el ruido estridente: "inmensa tormenta", "retumbar" o "gritos en los sótanos". Por su parte, el "exilio de la palabra" (Castro Flórez, 1994, p. 107) impuesto por el franquismo se traduce en la aceptación de un "silencio solo roto" por la resistencia clandestina que se materializa en las pintadas callejeras. Junto con esta dicotomía, se aprecian en los versos pinceladas de sesgo surrealizante ("pantano de lechuzas / y de niños sin dedos”), que transmiten la idea de la mutilación o una impresión de sordidez.

No menos llamativos son aquellos segmentos que abordan la agonía y muerte del "depredador":

Padre depredador que estás agonizando,

implacable parduzca mancha que se extiende en tu sábana,

que nos anega,

lo que nos has quitado

y el peso que pusiste en nuestras vidas,

el centro definitivamente es fuego,

disfruté la marea menstrual,

dormido golpeé a la mujer en el vientre,

gran petrificador.

(Gabriel y Galán, 2010, p. 195)

Se acabó el hombre dócil, el narrador sagaz.

Murió el depredador entre violetas y frases inconexas,

Nos han dejado solos,

¡ay de los baluartes,

la vieja guardia!,

se ve una tensa confusión de meritorios.

(Gabriel y Galán, 2010, p. 197)

A diferencia del enfoque histórico adoptado por Sahagún, la progresiva disolución del depredador en una "parduzca mancha” le permite a Gabriel y Galán desplegar una diversidad tonal en la que se amalgaman la parodia de la liturgia religiosa (el remedo del padrenuestro en la formulación inicial de la "plegaria" que se dedica al antihéroe), la referencia a una infecundidad de resonancias lorquianas ("marea menstrual", "vientre", "gran petrificador"), la impugnación del relato oficial del franquismo ("el narrador sagaz"), o la virulenta imprecación satírica a quienes temen la sucesión del régimen (“iay de los baluartes, / la vieja guardia!”), en sintonía con algunas de las piezas que Miguel Hernández o Max Aub dedicaron a quienes se beneficiaban de su anuencia con el poder.

En síntesis, el mosaico coral de Un país como este... aspira a recuperar el lenguaje del pueblo silenciado mediante una panoplia textual en la que tienen cabida la teatralización del pasado reciente, el registro crítico y la potencia visual de ciertas imágenes que no se someten a las cortapisas de la racionalidad. 


\section{Aprendices de brujo: Taller del hechicero y Tiempo y Práctica del círculo}

En Taller del hechicero, redactado entre 1974 y 1975, aunque publicado en 1979, Aníbal Núñez nos invita a sumergirnos en el trasmundo onírico de quien ha aceptado estoicamente su condición de outsider y se ha refugiado en una marginalidad basada en la "intemperie social y literaria" (Vives Pérez, 2015, p. 22). La reclusión del autor en su inexpugnable locus eremus trasluce la desilusión colectiva ante una realidad definida por la mercantilización de la cultura y la devastación de los recursos naturales. Sin embargo, más allá de la denuncia del consumismo irrestricto y de la protesta ecológica, hay aspectos que apuntan a un desencanto individual, como la experiencia del desarraigo o el fracaso de las ambiciones literarias4. No obstante, lejos de toda opción posibilista, la escritura de Aníbal Núñez intensificará desde mediados de los setenta una vertiente neobarroca (Vives Pérez, 2008, pp. 121-122) caracterizada por la mezcla de lo conceptual y lo experimental, los juegos de lenguaje y un deliberado hermetismo que metaforiza el triunfo del vacío y la consagración de la vanitas.

La composición metapoética que presta su título a Taller del hechicero ilustra este acercamiento:

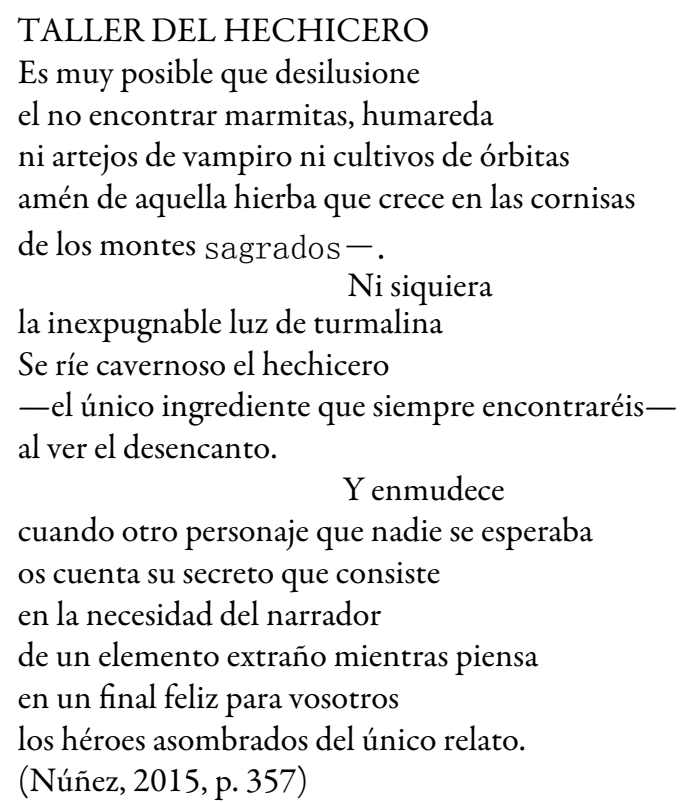

Mediante la disolución del "yo" en la impersonalidad del sujeto enunciativo, el texto propone un doble movimiento desmitificador: por una parte, la desacralización de la figura del poeta, que evoluciona desde una primitiva labor mediúmnica (la magia del hechicero) hasta una tarea meramente artesanal (el taller de la palabra) (Pardellas Velay, 2009, p. 399); por otra parte, la desacralización de la poesía, que evoluciona desde la efervescencia creativa (la ebullición de la marmita) hasta la mueca irónica (la risa cavernosa del hechicero). El descreimiento escéptico de la voz en off, que identifica el impulso lírico con un simple truco de magia, se desplaza en los versos finales hacia la silueta del lector. La ruptura de expectativas que implica la presencia de un intermediario entre el antiguo hechicero y el receptor actual no solo supone una interferencia metadiscursiva, sino que sugiere un tercer núcleo paródico: una desacralización de los destinatarios de la historia, acostumbrados a la univocidad moral de las fábulas y al happy end de los cuentos de hadas 5 .

Con todo, a Aníbal Núnez le interesan por igual el contenido del relato y el decorado taumatúrgico en el que se insertan símbolos convencionales, procedentes del acervo fantástico ("marmitas", "humareda", "artejos de vampiro", "cultivo de órbitas"), y símbolos crípticos ("montes sagrados”, "luz de turmalina”). Si los primeros refrendan la inversión de la imagen tópica del hechicero - como si se tratara de una revisión del cortometraje de animación "El aprendiz de brujo" - , los segundos parecen aludir tangencialmente a 
la drogadicción, a través de un lenguaje que oscila entre la "botica natural" y la "farmacia tóxica" (Labrador Méndez, 2009, pp. 315-321).

El clima malsano de "Taller del hechicero" entronca con la ópera prima de Juan Luis Ramos, un autor que había pasado casi inadvertido hasta la reciente publicación de su poesía completa: Con pájaros que ignoro (2017). Este rescate editorial ha contribuido a visibilizar un universo poético que tiene vinculaciones con la nueva épica, debido a la ubicación de los textos en lugares míticos y territorios evanescentes, y que participa de una "retórica del distanciamiento" (Mas, 2017, p. 24) en la que se dan cita los centelleos irracionales, la suntuosidad modernista y la manía anticuaria del sesentayochismo. Los versos de Ramos, a menudo habitados por criaturas mitológicas y falsos nigromantes, muestran reveladoras similitudes con Un pais como este no es el mio y con Taller del hechicero, aunque sin el correlato histórico del primero ni la dimensión metapoética del segundo.

Prueba de ello es "Ciénaga", incluido en Tiempo y práctica del círculo:

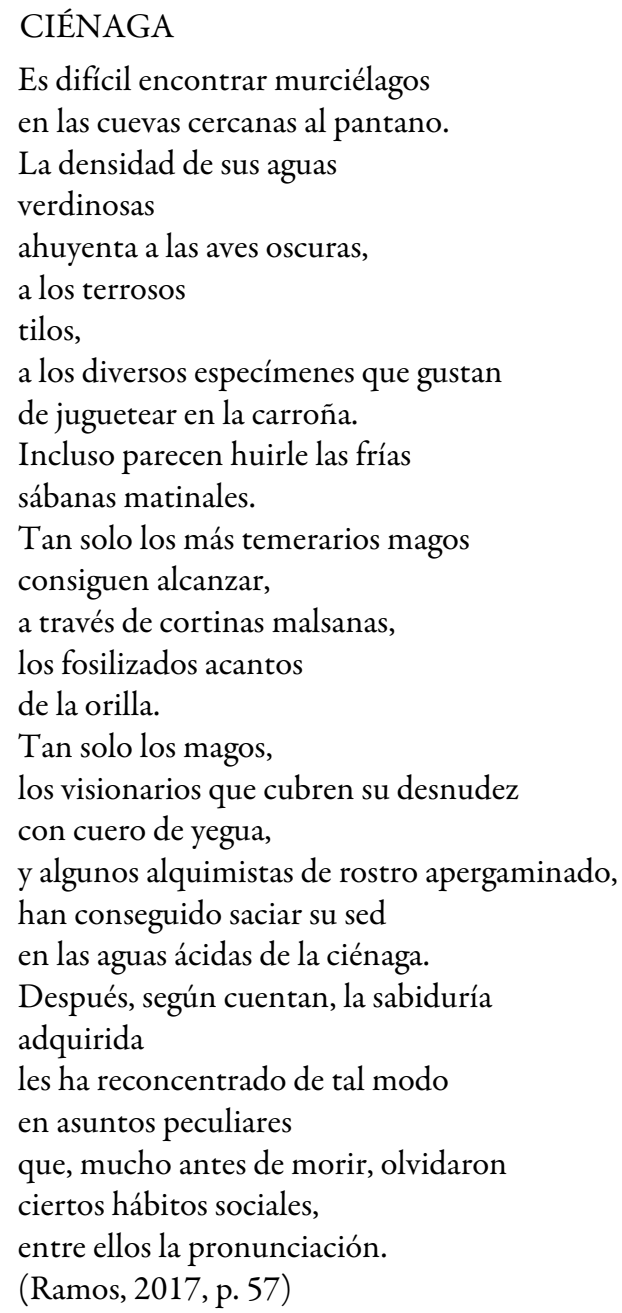

La atmósfera enrarecida del poema se intensifica gracias a la mención de la fauna (murciélagos, "aves oscuras", animales carroñeros), la geología (“cuevas cercanas al pantano", "fosilizados acantos”), el herbolario ("tilos") y hasta los personajes ("magos", "visionarios" y "alquimistas") que merodean por la ciénaga. Estos elementos remiten a un locus horribilis cuya densidad funeraria se relaciona con el ambiente tétrico de un cementerio o un pudridero: véanse los epítetos "aguas verdinosas", "aves oscuras", "terrosos tilos", "frías sábanas", "cortinas malsanas", "fosilizados acantos" o "aguas ácidas".

Sin embargo, como en "Taller del hechicero", estos ingredientes se incorporan a una receta que desborda los límites de la escenografía. En efecto, nos hallamos ante una parábola sobre el conocimiento que arranca 
de la estampa mitológica (la ciénaga como trasunto de la laguna Estigia) para proyectarse sobre la dualidad superficie / fondo. Como apuntan los versos finales, quienes transgreden la prohibición de beber de las aguas del pantano alcanzan la sabiduría, pero sufren la incapacidad de transmitirla, pues se atrincheran en el ensimismamiento y la mudez. En este corolario subyace una concepción del silencio y la locura como vías de acceso a una realidad superior ${ }^{6}$.

En conclusión, Aníbal Núñez y Juan Luis Ramos desempolvan el atrezo de la literatura gótica o del cine de terror en sendas fábulas que, bajo una cobertura irónica, reivindican la marginalidad vocacional del poeta y cuestionan la función social de la poesía durante la Transición.

\section{Paraísos artificiales: Primavera soluble y De una niña de Provincias que Se vino A VIVIR EN UN ChagaLL}

Primavera soluble refleja una característica frecuente en la producción de Aníbal Núñez: la asincronía entre la fecha de redacción y la fecha de publicación de sus títulos. De hecho, estamos ante un libro que adquiriría su definitiva formalización editorial en 1992, pero que toma como punto de partida el material encontrado en dos cuadernillos que el autor firmó en 1978. Esta obra resulta reveladora de lo que Rodríguez de la Flor (2012) ha llamado la "vida dañada" de Aníbal Núñez, relegada a la periferia geográfica y literaria. Del mismo modo, Primavera soluble ejemplifica los rasgos de una "escritura arrebatada" o una "literatura química" (Labrador Méndez, 2009) guiada por la huella de la adicción, en la que la invisibilidad del "cuerpo infectado" (Vilarós, 1998, pp. 246-258) se plasma a través de un complejo metafórico de arquitectura barroca.

Esta premisa se desarrolla en "El aguijón”, una alegoría de la drogadicción disfrazada bajo un envoltorio bucólico:

\section{[EL AGUIJÓN...]}

El aguijón -el pico rodea al pétalo-

trazará en el alcor tu inicial aún ignota,

coincida o no con el filón, un día

que se señalará con un silencio, un fruto

más. La ternura amarga, el estupor de

su blancor, su blandura a la tibieza

ser objeto invoca

del Roble en Primavera: No sé tu nombre, invento

la nieve alrededor, la nube navegante,

un olmedo en penumbra para que me lo digas.

(Núñez, 2015, p. 617)

En esta breve pieza convergen el compromiso ecológico ante la degradación de una "naturaleza no recuperable" y la referencia implícita a los paraísos artificiales de la heroína. De lo primero dan fe términos como "pétalo", "alcor", "fruto", "nube" u "olmedo". De lo segundo, una selección léxica fuertemente connotada, como "aguijón” y "pico" (correlatos recurrentes de la jeringuilla), "nieve” (destilación de la blancura) o "penumbra” (sinécdoque dela clandestinidad). La síntesis de esos dos mundos - según se aprecia en el hermetismo de una imagen como "Roble en Primavera", con mayúsculas en el original - se sutura mediante el nexo simbólico del lenguaje, capaz de cubrir la aparente distancia entre las isotopías que se superponen en la composición.

Distinto es el caso de Blanca Andreu, que desde su bautismo editorial recibiría la atención de críticos y la devoción de los lectores. Su primer libro, De una niña de provincias que se vino a vivir en un Chagall, publicado en 1981 tras obtener el premio “Adonais", se erigiría en un título emblemático del momento. En sus páginas, un "yo" generacional (Lanz, 2007, pp. 328-330) transmitía su desolación por la angustiosa pérdida de la adolescencia. De una niña... giraba en torno a tres ejes temáticos: el amor, con la iniciación a la sexualidad 
como leitmotiv; la muerte, no exenta de cierta morbosidad funeraria; y una escritura de la dependencia o una "poética drogada" (Morales Barba, 2012) que se manifestaba en expresiones como "venas que se adormecen para querer morir" (1994, p. 39), "niñas de oro hipodérmico que nunca creen morir" (p. 62) o "con el pico de plata y de ginebra" (p. 62).

El libro de Andreu, que inauguró con notable fortuna una escuela neosurrealista a comienzos de los ochenta - a esta corriente se adhieren títulos tempranos de Miguel [Ángel] Velasco (Las berlinas del sueño, 1982) o Fernando Beltrán (Aquelarre en Madrid, 1983), entre otros -, estaba recorrido por una pulsión alucinatoria que se inspiraba en imágenes extraídas de una vivencia real. Al igual que ocurría en Aníbal Núñez, los paraísos artificiales se integran ahora dentro de un universo metafórico ligado a la naturaleza (Labrador Méndez, 2009, p. 246).

Así se observa en el poema que comienza con el verso "En las cuadras del mar duermen términos blancos":

[EN LAS CUADRAS DEL MAR...]

En las cuadras del mar duermen términos blancos,

la espuma que crepita, la droga hecha de liquen que mueve a olvidar:

en los establos del mar reina la urraca, la intriga y la discordia,

nueva versión del agua y del bajo oleaje,

nueva versión del agua derramada desde todas las tierras y las tapias del mundo.

Entre los muros del mar callan los abedules que poseen los símbolos del mirlo,

la última voz del bosque,

calla la yedra bárbara que envenenaba ciervos leves como navajas,

el roble boreal,

arrendajos dormidos como libros celestes, incendios y lechuzas de la grava marina.

En las caballerizas del mar, el mar se ahoga con su métrica ardiente,

la flora, las ojivas y las bocas del mar,

concilio de castaños en vilo verdeherido,

y alguien desde muy lejos abdicando, andando desde lejos a morir entre lejanas

ramas empapadas:

alguien desde muy lejos esperando la flora, las ojivas y las bocas del mar.

Entre noviembre y cascos y corolas

el ángel de los remos camina ensangrentado con olor a madera,

con pupila de pájaro el otoño gravita,

acecha el ángel de los cables y las oscuras verjas, los reductos malignos,

y el ángel de la arcilla, matriz de zarza,

polen y estela de placenta que en otoño florece en muerte.

En las caballerizas del mar el mar se ahoga con su métrica ardiente.

Entre los muros del mar callan los abedules que poseen los símbolos del mirlo avisador.

En las cuadras del mar, como en la muerte,

duermen términos blancos.

(Andreu, 1994, p. 70)

El turbión visionario nos arrastra hacia una dialéctica donde combaten la destrucción y la regeneración, el plano terrestre y el nivel ascensional. No en vano, el léxico escogido entrelaza vocablos asociados al espacio marino ("espuma”, "oleaje”, "agua derramada”, "ramas empapadas"), la botánica ("abedules”, "bosque”, “yedra”, “roble”, “castaños”, “zarza”), la ornitología ("urraca”, “mirlo”, “arrendajos”, "lechuzas”, “pájaro”) y la drogadicción ("droga hecha de liquen", "términos blancos”, "navajas”, "reductos malignos”, o "caballo", que se infiere metonímicamente de la palabra "cuadras"). La sensación de ahogo que deriva de la estructura paralelística y la iteración versicular certifica la contigüidad metafórica entre el olvido, la ensoñación y la muerte.

En definitiva, la eclosión de los paraísos artificiales en la lírica de finales de los setenta y comienzos de los ochenta constituye otra manera de transgredir la norma de una Transición civilizada, al introducir la mágica alquimia de las drogas y la reactivación del discurso de los márgenes. 


\section{Recapitulación}

Como se ha visto, frente al predominio de la estética realista, otras transcripciones literarias de la Transición optaron por manifestar su disidencia mediante un profuso código simbólico. Las lecturas político-ideológicas promovidas por Carlos Sahagún y José Antonio Gabriel y Galán revelaban, a través de un lenguaje alegórico o de una trabazón épica, un profundo desengaño político. El fracaso de las expectativas transformadoras depositadas en el posfranquismo se contrarrestaba en estos autores con la voluntad de recuperar la memoria colectiva y el deseo de romper la cadena genealógica de la derrota. Por su parte, las lecturas socioculturales auspiciadas por Aníbal Núñez, Juan Luis Ramos o Blanca Andreu daban carta de naturaleza a un desencanto generacional que se conjuraba gracias a la reflexión metapoética o que se refugiaba tras el muro intransitivo de una adicción sugerida en metáforas de difícil intelección. En suma, el éxito de la Transición ilustrada acabaría por extinguir el fuego de esa otra Transición mágica que pudo haber sido y no fue. Al fin y al cabo, tampoco Moratín llegó a volar a lomos de una escoba.

\section{REFERENCiAS}

Andreu, B. (1994). El sueño oscuro. Poesía reunida 1980-1989. Madrid: Hiperión.

Aute, L. E. (2000). Urgía liberarse del pecado [entrevista]. La Vanguardia, 4 de noviembre.

Bagué Quílez, L. (2010). Jugando con fuego: la poesía de José Antonio Gabriel y Galán. En J. A. Gabriel y Galán, Último naipe (Poesía completa, 1970-1990) (pp. 29-89). Mérida: Editora Regional de Extremadura.

Bagué Quílez, L. ([2017] 2018). Dichos y hechos: la poesía “social” de Carlos Sahagún. En La poesía española desde el siglo XXI. Una genealogía estética (pp. 135-144). Madrid: Visor.

Castro Flórez, F. (1994). La escritura del náufrago. En VV. AA.,José Antonio Gabriely Galán. Reflexiones sobre su vida y obra (pp. 101-110). Mérida: Editora Regional de Extremadura.

Gabriel y Galán, J. A. (2010). Último naipe (Poesía completa, 1970-1990). Mérida: Editora Regional de Extremadura. García Martín, J. L. (1992). La poesia figurativa. Crónica parcial de quince años de poesía española. Sevilla: Renacimiento. Labrador Méndez, G. (2009). Letras arrebatadas. Poesia y química en la Transición española. Madrid: Devenir.

Lanz, J. J. (2007). La poesia durante la Transición y la generación de la democracia. Madrid: Devenir.

López, J. (1979). En busca de la poesía épica: del nuevo estilo a la nueva moral. Nueva Estafeta, 9-10, 126-132.

Mainer, J. C. (1996). Sahagún contra Franco. Poesía en el Campus, 35, 21-24.

Mas, M. (2017). La poesía de Juan Luis Ramos en su contexto. En J. L. Ramos, Con pájaros que ignoro. Poesia reunida (pp. 5-23). Barcelona: Ultramarinos.

Molina Campos, E. (1979). Lírica y épica de José Antonio Gabriel y Galán. Nueva Estafeta, 7, 87-89.

Morales Barba, R. (2012). Blanca Andreu y Miriam Reyes desde el poema drogado o la negación del cuerpo. En M. J. Zamora Calvo y A. Ortiz, Espejo de brujas: mujeres transgresoras a través de la historia (pp. 209-224). Madrid: Abada.

Núñez, A. (2015). Poesía reunida (1967-1987). Madrid: Calambur. Edición de Vicente Vives.

Oleza, J. (1996). Un realismo posmoderno. Ínsula, 589-590, 39-42.

Pardellas Velay, R. (2009). El arte como obsesión. La obra poética de Aníbal Núñez en el contexto de la poesía española de los años 70 y 80. Madrid: Verbum.

Ramos, J. L. (2017). Con pájaros que ignoro. Poesia reunida. Barcelona: Ultramarinos.

Rodríguez de la Flor, F. (2012). La vida dañada de Aníbal Núnez. Una poética vital al margen de la Transición española. Salamanca: Delirio.

Romarís Pais, A. (2002). El oficio sombrío de Carlos Sahagún: Primer y último oficio. Cuadernos para Investigación de la Literatura Hispánica, 27, 331-364. 
S. F. (1980). Carlos Sahagún: 'La poesía actual española pasa por un momento desconcertante'. $A B C, 13$ de diciembre. Sahagún, C. (2015). Poesías completas (1957-2000). Sevilla: Renacimiento.

Vilarós, T. M. (1998). El mono del desencanto. Una crítica cultural de la transición española (1973-1993). Madrid: Siglo XXI.

Vivanco, L. F. (1972). Moratín y la Ilustración mágica. Madrid: Taurus.

Vives Pérez, V. (2008). Aníbal Núñez, la voz inexpugnable. Alicante: Universidad de Alicante.

Vives Pérez, V. (2015). Breves trazos para una poética indómita. En A. Núñez, Poesia reunida (1967-1987) (pp. 13-40). Madrid: Calambur.

\section{Notas}

1 Este artículo se halla vinculado al Proyecto de Investigación del Plan Estatal "Poéticas de la Transición (1973-1982)" Ref. FFI2017-84759-P (AEI/FEDER, UE).

2 La condena de estas ejecuciones está en el origen de una de las canciones más célebres (y celebradas) de la Transición: "Al alba", compuesta por Luis Eduardo Aute y popularizada gracias a las versiones que realizaron Rosa León (en 1975) y el propio Aute (en 1978). A este respecto, en una entrevista recogida por el diario La Vanguardia, Aute (2000, p. 22) declaraba lo siguiente: "Escribí 'Al alba' los días previos a los fusilamientos y con mucha urgencia. Debe haber sido una de las canciones que más rápidamente me surgieron, pero quería que la gente la cantara. La verdad es que no tuve que pensar mucho, salió del dolor".

3 La insólita aportación lírica de Gabriel y Galán, rastreable en tres poemarios muy dispares, podría complementarse con una producción narrativa sumamente crítica con las concesiones ideológicas y las componendas políticas de la Transición, como manifiestan El bobo ilustrado (1986) y, sobre todo, Muchos años después (1991).

4 Desencanto es una palabra clave en el periodo transicional: así lo rubrica el rótulo de la famosa película (1976) de Jaime Chávarri sobre la familia Panero, a medio camino entre el biopic coral y el docudrama.

5 No olvidemos que Núnez había recurrido al desmontaje irónico de los mecanismos propios de los cuentos tradicionales en algunas de sus Fábulas domésticas (1972), como "Caperucita roja", "Aquí os quisiera ver astuto gato" u "Otro final para el cuento de la lechera".

6 Esta es una de las inquietudes recurrentes en la poesía de Leopoldo María Panero, el "maldito oficial" del sesentayochismo.

7 Recordemos que Elpico (1983) es el título de la película de Eloy de la Iglesia que se convertiría en icono del cine "quinqui". 